\title{
Differentiation of Head Shapes and Positions of Shadow Puppets Arjuna Kedhu and Kinanthi in Surakarta Style
}

\author{
Ratna Cahaya Rina Wirawan* Yasraf A. Piliang Ira Adriati Irfansyah \\ Doctoral Program in Science Art of Desig, Institut Teknologi Bandung
}

\begin{abstract}
This research was conducted to see the differentiation of the shape and position of the head which shows the different concepts in Arjuna's self-control which are famous for its ability to control themselves. These different concepts occur over time by the creation of Arjuna wanda (specific expressions of puppets) of Kedhu, Kinanthi, and Muntap created in different centuries and eras. The method used in this research is ethnosemiotic which is a combination of ethnographic and semiotic methods by analyzing three wanda, namely wanda Kedhu, Kinanthi, and Muntap. The results obtained indicate that Kinanthi has a slighter differentiation from Kedhu, but Muntap has a wider differentiation. This differentiation is related to the size of the hair bun, the angle of the forehead, the angle of the eyes and the position of the head. This shows that there are gradations of expression from the three wanda, where the happy expression on the Kinanthi wanda mediates the pious expression of the Kedhu wanda and the wrath of the Muntap wanda.
\end{abstract}

Keywords: head, shapes, positions, expressions, differentiations

DOI: $10.7176 / \mathrm{ADS} / 76-04$

Publication date:September $30^{\text {th }} 2019$

\section{Introduction}

One important figure in Javanese ancient shadow puppet show is Arjuna, who is the third Pandava knight in the Mahabharata story. The characterization of Arjuna written in Ambeg Songo - an ancient literature work - which is part of Centini links the nature of Arjuna with the ability to control oneself, kindness, calmness, and intelligence. These characteristics are considered as an ideal example of men for the Javanese [1], Lelananging Jagad (the most masculine man in the entire universe) [2] and the symbol of a perfect man [3].

The ability to control oneself is the source of virtue because virtue is also related to the ability to hold thoughts and bad intentions, to control feelings so that they can display calm, and can encourage to think clearly so that their intelligence can stand out. Self-control is also an emotional control is an attitude that is highly valued by the Javanese, although angry but can still hide his anger and still be patient [4].

The most masculine figure in the entire universe in shadow puppets is depicted as a figure characterized by having a small body size, wearing cloth (bulging in the back), minimum accessories, the position of his head bowed, and the distance between his legs narrow. These forms consistently appear in other Arjuna's wanda, which numbers at least 10 shadow puppets. Wanda is a form of character with a variety of expressions wich use interchangeably depends on the story being told in the performance.

The consistency of the form is due to Arjuna's emotional range which is not too contrasting, given the character's special feature is its ability to hold emotions. This causes the Arjuna's puppets looked similar to each other at a glance, even though when viewed in more detail there are differences. A difference of one or two millimeters in the shape and position of Arjuna's wanda can give very different impressions and expressions. Differentiation of the forms and meanings of the three wanda is interesting to study to see the strategy of the expression of Arjuna's character in shadow puppets within the limited range of Arjuna's emotions.

This article is part of a dissertation study about the differentiation of the figure of Arjuna shadow puppets in Surakarta style. The expressions of the characters that appear on the wanda should not only be understood from the head, but the whole body, related to the shape, position, and gesture. However, it is undeniable that the head is an important part of the expression of shadow play. One of the processes in making puppets is the 'facial dissection' carried out by the "surgeon", a special carver who understands the character's expression. Several studies on shadow puppets have been done, but none have focused on the differentiation between the Arjuna shadow puppets.

\section{Method}

This research is structuralist qualitative research using ethnosemiotic method, which is called Fiske as a semiotic reading of ethnographic data [5]. Research techniques carried out in ethnography are considered Fiske not valid enough, because of the possibility of bias in interpreting the data [5], so that the reading of semiotics can provide a more measurable interpretation. Pozzato supports the use of this two-stage analysis by saying that the ethnosemiotic method can be used to look deeper through different perspectives on the visualization mechanism of society in seeing its culture [6].

The data used in this study were observations in the form of three Arjuna shadow puppets and the results of 
interviews. The three of them are documented in the form of photographs accompanied by written descriptions and interview transcripts with informants who have been categorized according to the theme. The selected artifacts are Arjuna shadow puppets Kedhu, Kinanthi, and Muntap which are carved with Bambang Suwarno's patron, with Arjuna Kedhu as a benchmark to see differentiation. Kedhu is the oldest wanda (around the 15th century AD) which is used as the basis for the creation of the next Arjuna wanda so that this puppet is the mother of all wanda. Kinanthi which was created around the 19th century AD is also popular because it is flexible to be used in scenes of war and romance. Muntap is the most recent wanda (20th century AD) which is considered the most suitable for war scenes. These three shadow puppets were chosen to be analyzed for their differences, using Arjuna Kedhu as a starting point for benchmarking.

There are several stages of analysis carried out with a typical ethnographic method combined with semiotics, beginning with a domain analysis that identifies the elements contained in the Arjuna shadow puppet. The taxonomic analysis is carried out by exploring in more detail the internal structure of the domain found. The next step is differentiation analysis to look for differences between the three Arjuna shadow puppets. Barthes said that signification can be done in two stages, the first signing is produced as the second signing material which sees a more conceptual view of the object being a signifier. The meaning presented in this article only covers the first stage of meaning, to validate the differentiation between the three signs analyzed.

\section{Arjuna's Head Shapes and Positions}

The position of Arjuna's head in general bowed, to maintain his eyesight and not to spit emotions, as a sign of his ability to control himself. The Javanese consider that opening up feelings, acting suddenly, spontaneously, is a reaction that shows inner turmoil and lack of self-control ability is considered to be a bad thing [7]. Through Suseno's statement, it can be understood that a good Javanese person must be able to display subtle behavior and language and be good at hiding his feelings. Good self-control is important for Javanese people because it can avoid conflict that can interfere with social harmony. For Javanese, not disturbing social harmony in society is more important than creating harmony [7].

Arjuna who is said to be the most perfect man for Javanese has a high ability in self-control. Self-control is the control of passion related to emotions, ambitions, and desires related to worldliness. The Javanese consider that these mundane things are lodged in the body, so humans must be able to control their bodies physically and mentally. Physical control of the body is done by asceticism and fasting so that his mental desires are stronger in controlling his body, not vice versa. Mental control of the body is done by distance from the world, through the attitude of willingness, acceptance, and patience [8]. Willingness is the sincerity of the heart surrendering all its possessions to God. Acceptance that everything that happens to him is given by God. Patience is carried out by being willing and accepting wholeheartedly. These attitudes are passive, but the passivity can only be done by strong humans who can control themselves.

\subsection{Differentiation of Arjuna's Head elements}

Arjuna puppet has a special shape that is not drawn like human, but can still be recognized as human. The ratio between the size of the shadow puppet head and the rest of his body is $1 \mathrm{x}: 1 \mathrm{x}: 1.5 \mathrm{x}$, in contrast to human who has 1x: 8x with 1x being the height of the head (see Figure 1, left). Arjuna's head part consists of several elements, namely the eyes, nose, forehead, lips, neck, shoulders, hair bun, sumping (hairpiece), and earrings. The elements in the three wanda (Kedhu, Kinanthi, Muntap as seen in Figure 1) analyzed do not all have differentiation, some of these elements are repetitions. The focus of the analysis is on the elements of the head part of shadow puppet Arjuna that has differentiation, but the elements which are repetitions are still interpreted. Deleuze said that the concept of differentiation cannot occur singly, but is related to other elements as in a structure so that it can be distinguished from other elements [9]. The elements that have no differences in the three shadow puppets are the nose, lips, chin, cheek area, ears, sumping, and earrings. The different elements are the forehead, eyes, bun, neck, and shoulders. The components analyzed for these elements can be seen in Table 1.
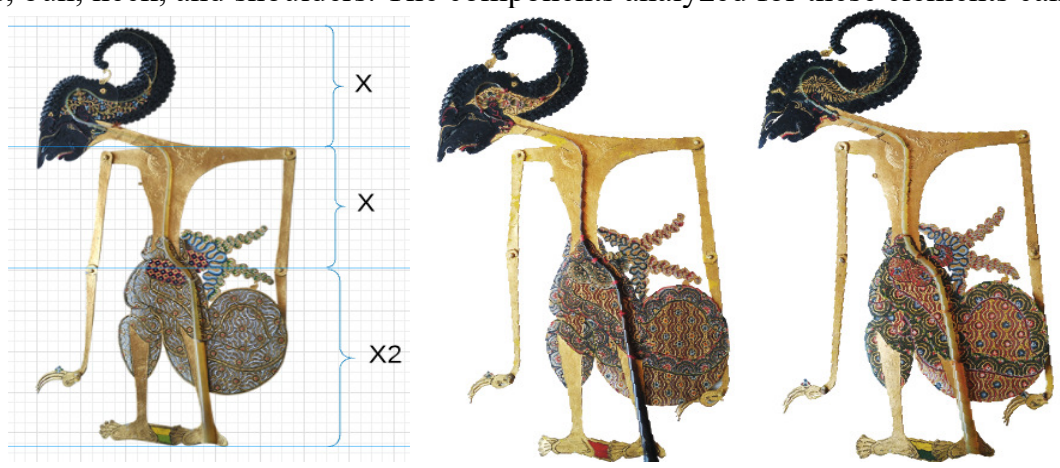

Figure 1. Arjuna Kedhu (left), Kinanthi (middle), Muntap (right) 
Table 1. Component Analysis of Shadow Puppet Arjuna's Head

\begin{tabular}{|l|l|l|}
\hline Differentiations/repetitions & \multicolumn{1}{|c|}{ Head elements } & \multicolumn{1}{|c|}{ Component } \\
\hline \multirow{4}{*}{ Differentiations } & Hair bun & Shape, position, size \\
\cline { 2 - 3 } & Temple & Shape \\
\cline { 2 - 3 } & Eyes & Position \\
\cline { 2 - 3 } & Neck & Shape, position \\
\cline { 2 - 3 } & Head & Position \\
\hline Repetitions & Cheek, ears, nose, lips, sumping (hairpiece), earrings & Shape \\
\hline
\end{tabular}

The analysis is done mathematically based on angles and grids, where the value of 1 grid is equivalent to $\mathrm{x}$. Some elements are related to other elements, such as the shape of the forehead that cannot be separated from the shape of the nose because they are fused. Another element is the head and neck because the shape and position of the neck cannot be separated from the head.

\subsubsection{Hair Bun}

The hair bun that Arjuna wears is called Supit Urang because it is shaped like a shrimp claw but looks like a curved horn from one side. The components analyzed in the bun are the shape, position, and size. Each bun has a designation, namely Supit Urang Bunder Merit bun (small round shrimp claw-shaped bun), round and Landing Supit Urang bun (round bun-shaped shrimp claw rising to the top), and large oval Supit Urang bun. The calculation results can be seen in Table 2 .

Table 2. Differentiations of Arjuna's Hair Bun

\begin{tabular}{|l|l|l|l|}
\hline \multicolumn{1}{|c|}{ Wanda } & \multicolumn{1}{c|}{ Kedhu (benchmark) } & \multicolumn{1}{c|}{ Kinanthi } & \multicolumn{1}{c|}{ Muntap } \\
\hline $\begin{array}{l}\text { Shape } \\
\text { component }\end{array}$ & $\begin{array}{l}\text { The bun is round with a crest } \\
\text { that isn't too tall. The height } \\
\text { between the bun points under } \\
\text { the ear to the top of the crest is } \\
\mathrm{Y}=0.8 \mathrm{x}\end{array}$ & $\begin{array}{l}\text { The bun is round and is higher } \\
\text { above the head with bangs that } \\
\text { are also higher, about the size } \\
\text { of the Kedhu } \text { wanda, the value } \\
\text { of } \mathrm{Y}=0.8 \mathrm{x}\end{array}$ & $\begin{array}{l}\text { Bangs raised high so that } \\
\text { leaves space between the } \\
\text { tip of the bangs and head. } \\
\text { Y value }=0.925 \mathrm{x}\end{array}$ \\
\hline $\begin{array}{l}\text { Position } \\
\text { component }\end{array}$ & $\begin{array}{l}\text { The angle between the lower } \\
\text { end of the bun and the } \\
\text { beginning of the outer ring of } \\
\text { the bun is } 14^{\circ}\end{array}$ & $\begin{array}{l}\text { The lower end of the bun with } \\
\text { the beginning of the outer ring } \\
\text { being } 17^{\circ} \text { shows the position } \\
\text { of the bun high }\end{array}$ & $\begin{array}{l}\text { The lower end of the bun } \\
\text { with the beginning of the } \\
\text { outer ring being } 12^{\circ} \\
\text { indicates the position of the } \\
\text { bun is low }\end{array}$ \\
\hline $\begin{array}{l}\text { Size } \\
\text { Component }\end{array}$ & $\begin{array}{l}\text { Small in size, with dimensions } \\
\mathrm{X}(\text { length) }=2.575 \mathrm{x} \text { and } \mathrm{Y} \\
\text { (height) }=2.1 \mathrm{x}\end{array}$ & $\begin{array}{l}\text { Slightly smaller, with } \\
\text { dimensions } \mathrm{X}=2.5 \mathrm{x} \text { and } \mathrm{Y}= \\
2.075 \mathrm{x}, \text { but seem higher than } \\
\text { the Kedhu } \text { wanda }\end{array}$ & $\begin{array}{l}\text { Oval size, with dimensions } \\
\mathrm{X}=2.75 \mathrm{x} \text { and } \mathrm{Y}=1.96 \mathrm{x}\end{array}$ \\
\hline
\end{tabular}

The shape differentiation can be seen from the crest shape associated with the height between the lowest point and the highest point of the bun which is calculated by the y value marked in blue (see Figure 2). The results obtained indicate that the Muntap bun is higher than the Kedhu and Kinanthi bun (see Table 1). The position of the bun is calculated from the angle drawn from the lower end of the bun with the beginning of the outer ring marked in red (see Figure 2). The results showed that the position of the Kinanthi bun was higher than the Kedhu, while the position of the Muntap bun was lower than the Kedhu and Kinanthi. Differentiation of size can be seen from the length and height $\mathrm{x}$ value of the whole bun and the results obtained that the height of the three buns is not much different, but the Arjuna Muntap bun is longer than the Kedhu and Kinanthi, so it appears larger.

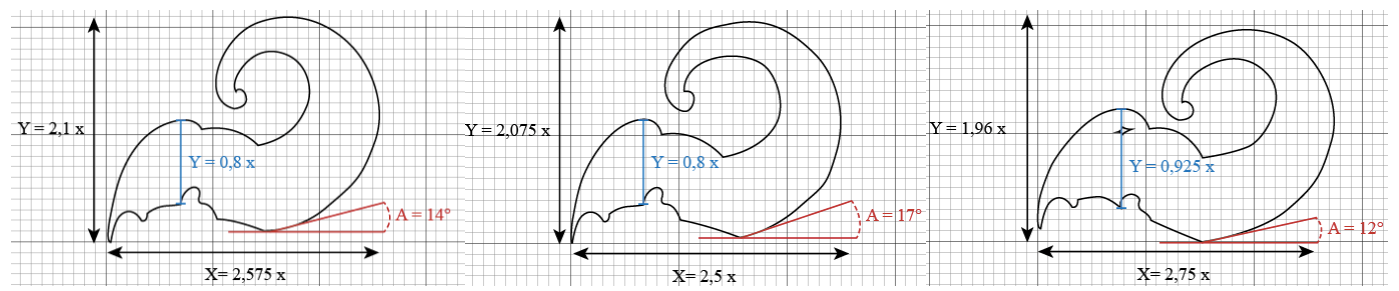

Figure 2. Arjuna Kedhu's hair bun (left), Kinanthi (middle), Muntap (right)

\subsubsection{Forehead}

The nasal line extending from the endpoint of the hairline to the forehead is used to see the differentiation of Arjuna's forehead. Arjuna's forehead differentiation can be seen from its slope which is calculated by drawing a line following the nose line (y2) and a vertical line perpendicular (y1) that cuts precisely at the lower end of the nose. The width of the angle between these two lines can be used to see the difference in the slope of Arjuna's forehead. The results obtained indicate that the angle of Arjuna Kedhu and Kinanthi has the same slope angle (A), which is $6^{\circ}$, while Muntap has a greater slope, which is $19^{\circ}$ (see Figure 3). 

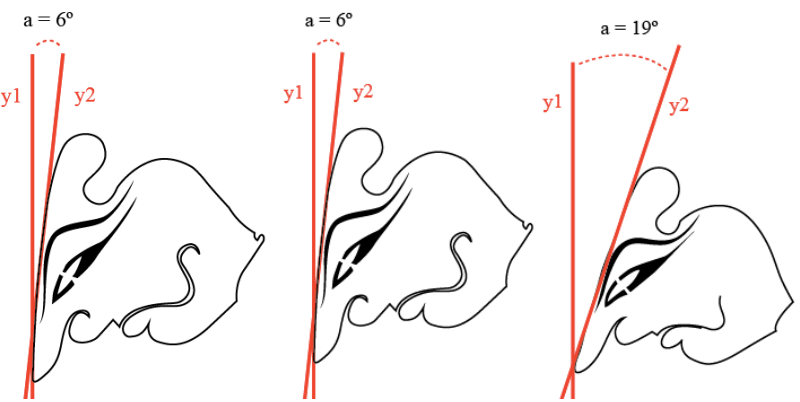

Figure 3. Arjuna Kedhu's forehead (left), Kinanthi (middle), Muntap (right)

\subsubsection{Eyes}

The eyes on the three Arjuna wanda were observed to have a form called the Liyepan Bedhahan Blebes eyes, which were shaped like a small slit with the bottom line of the eye forming a smooth curve like a straight line. The three eyes have different eye tilt angle which is calculated through the angle (A) that is formed between a straight line taken from the bottom point of the eye (x1) toward the meeting point between the upper and lower line of the eye with a horizontal line (x2) taken from the point taken same. The results show that the angle A between $\mathrm{x} 1$ and $\mathrm{x} 2$ on Kedhu and the Kinanthi (see Figure 4) only differ by $1^{\circ}, 50^{\circ}$ for Kedhu and $49^{\circ}$ for the Kinanthi, while the A angle for the Muntap is $41^{\circ}$. This shows that the eye position of Arjuna Muntap is lower than Arjuna Kedhu and Kinanthi.

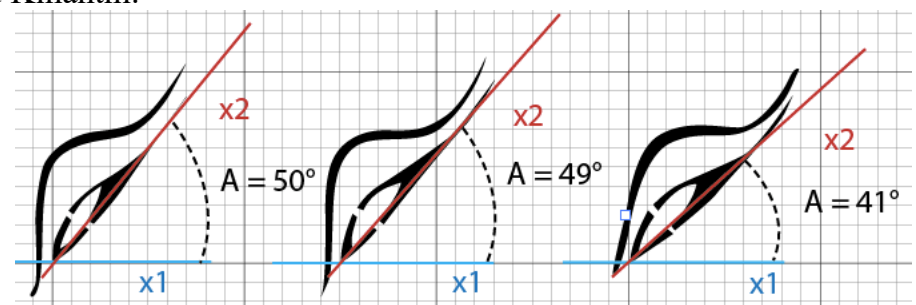

Figure 4. Arjuna Kedhu's eye tilt (left), Kinanthi (middle), Muntap (right)

Another differentiation found between the three eyes is the distance between the endpoint of the lower end of the eye line (x1) and the bottom line of the eyebrows (x2), which is calculated through the angle (A) formed between the two, if the initial line starts from the lower end of the eye. It can be seen in Figure 5 that the angle $\mathrm{A}$ formed from $\mathrm{x} 1$ and $\mathrm{x} 2$ in Arjuna Kedhu is greater than the Kinanthi wanda, while Muntap has the smallest A angle. A smaller angle between the tip of the eye with the eyebrows and the meeting point of the lower and upper eye lines with the horizontal line on Arjuna Muntap with the other two shadow puppets is used to show the intensity of Arjuna's emotions in battle in a state of anger and alertness.

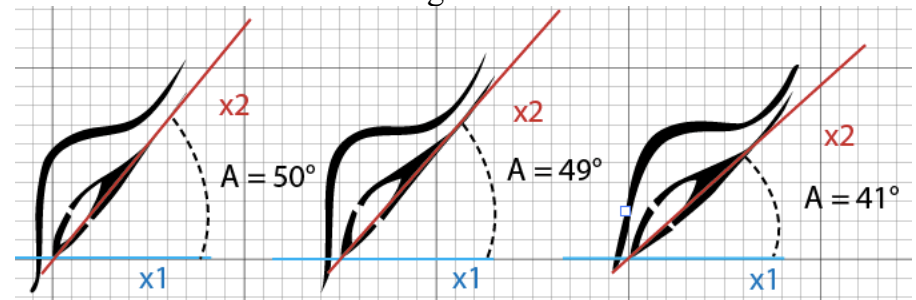

Figure 5. Arjuna Kedhu's eye to eyebrow distance (left), Kinanthi (middle), Muntap (right)

\subsubsection{Neck and Head}

Arjuna's neckline is the link between the shoulders and head so that its position depends on the position of the head which becomes the more important determinant to give Arjuna's shape characteristics. The third neck of the observed Arjuna shadow puppets have the following terms: Arjuna Kedhu's neck is called the Manglung neck (protruding), while Arjuna Kinanthi has a straight, protruding, and long neck, and the neck of the Muntap wanda is short. Differentiation of the three Arjuna necks observed was seen from the size and position components. The neck size between Arjuna Kedhu and Kinanthi is not too much different. This measure is produced by calculating the length of the $\mathrm{x} 1$ line drawn following the neckline to the point of meeting with the $\mathrm{x} 2$ line drawn following the chin line (see Figure 6). The measurement results show that the neck of Arjuna wanda Kedhu is slightly longer (1.55x) than Arjuna wanda Kinanthi and Muntap (1.5x). 


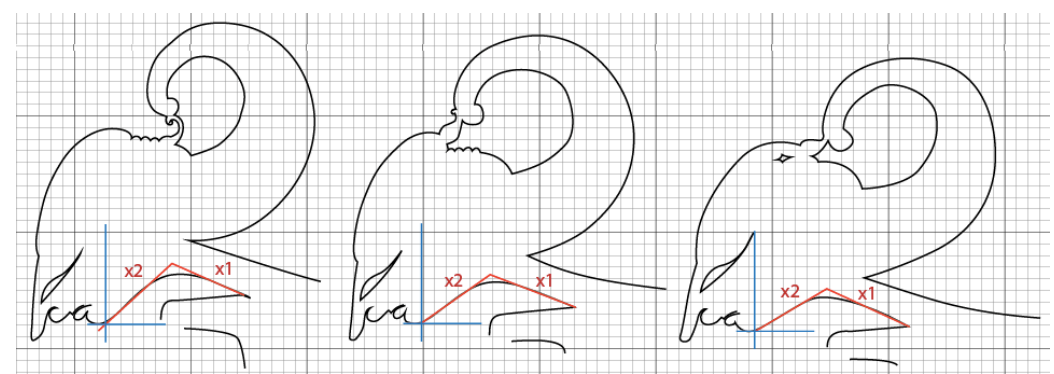

Figure 6. Arjuna Kedhu's neck (left), Kinanthi (middle), Muntap (right)

The impression that the neck of Arjuna Kinanthi is longer than the Kedhu and the neck of Muntap is the shortest of the three due to the shape of the neck is also influenced by the position of Kinanthi's head extending further. The position of Arjuna Kedhu's head which is calculated by the distance (Y) between the horizontal line taken from the point at the end of the chin (x1) and the lowest line on the front of the shoulder (x2) appears wider than Y on the Kinanthi and Muntap (see Figure 6). This wide Y distance indicates that the position of the head of Arjuna Kedhu looks very bent so that although the length of the neck is only $0.5 \mathrm{x}$ different from the other two shadow puppets, it gives the impression that the neck is longer. While on the Muntap, the narrow Y line indicates that the position of the head looks up and gives the impression of a shorter neck (see Figure 7).

Arjuna's neck that was very bent on the Kedhu signified obedience because Kedhu was generally used for puppet plays related to religious stories. This position is different from Arjuna Muntap who looks up to show Arjuna is looking at the enemy cautiously and expressing anger. While the neck position of Arjuna Kinanthi is between Kedhu and Muntap which is used to show a calm mood and fall in love. Feelings of falling in love like Kinanthi and piety in the Kedhu are feelings of calm, so the differentiation between the two elements is not too far when compared to the Muntap.

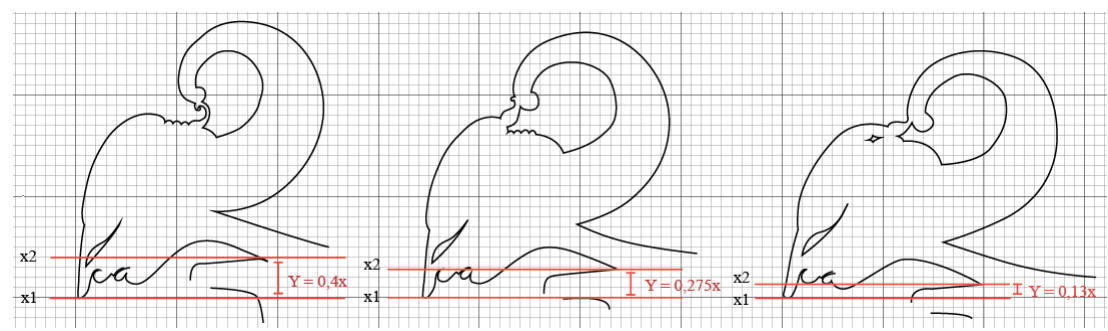

Figure 7. Arjuna Kedhu's head positions (left), Kinanthi (middle), Muntap (right)

\subsubsection{Sumping (Hairpiece)}

Sumping is a hairpiece that placed on Arjuna's ear. The shadow puppets are given the freedom to fill the sumping motif, but certain wanda generally use Parisewuli (grain) and Waderan (small fish) sumping. Arjuna Kedhu and Kinanthi wear sumping with Parisewuli motif, while Arjuna Muntap wears sumping with Waderan motif (see Figure 8). Sumping Waderan is related to the special character of Arjuna who is always thirsty in seeking knowledge. Arjuna never stopped to wander to find a teacher and do ascetic to seek knowledge. This is likened to a fish that continues to move in the water, as it is decorated with Arjuna's sumping. Arjuna's knowledge in his wandering is used to maintain the peace and security of the people so that his presence is important for the community. Although many people who need it, Arjuna does not necessarily become arrogant, but still humble. The Parisewuli sumping which depicts a bundle of rice represents two signs, namely: Arjuna is needed by the community as well as rice which is the staple food of the community and Arjuna remains humble like bent rice plants.
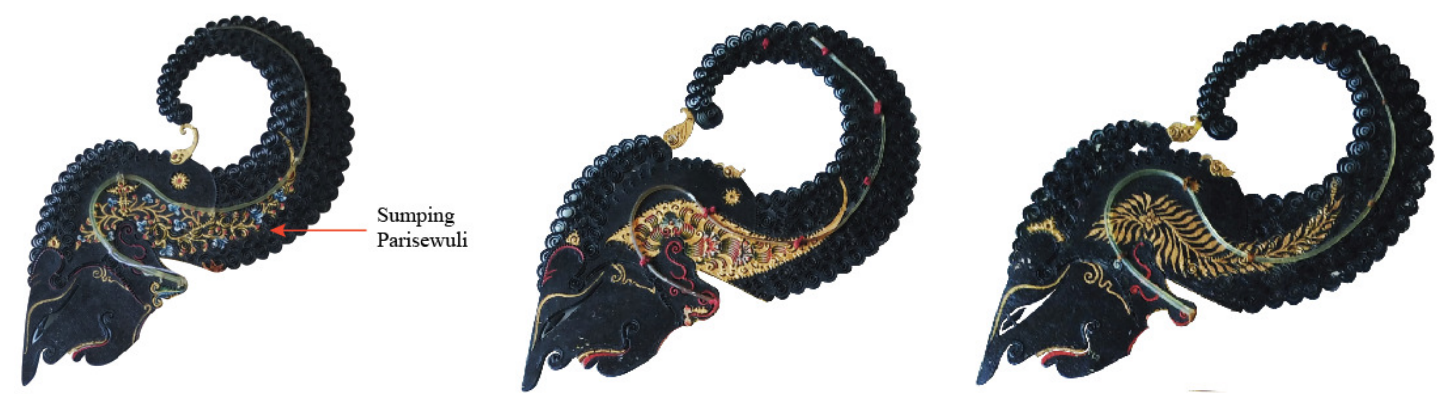

Figure 8. Arjuna Kedhu's sumping (left), Kinanthi (middle), Muntap (right) 


\subsection{Repetition of Arjuna's Head Elements}

Other elements in the heads of Arjuna Kinanthi and Muntap are the repetition of the elements in Arjuna Kedhu. These elements have meaning and function to support and strengthen the characterization of Arjuna as an ideal Javanese man. An explanation of these elements is as follows:

- Ambangir nose (sharp). Arjuna's nose is small with a pointed tip pointing down like a female character. The shape of the nose is small and pointed shows a mild temper, while the position of the fall of the nose shows modesty. The more bent the nose position, the character shows that the character is humbler. On the contrary, the more looked up, the more arrogant or brave the character. The position of the nose is also related to the position of the head.

- Salitan lips. Arjuna's lips are thin with a small closed position, but a small portion of his teeth appear flat, seen from the side. Mouth covered in a mild temper, permitted speech, and not greedy. These attitudes are a form of self-control with controlled movements, arrogance, which can damage the harmony of society.

- Lombok Sakpelik (small chili) earrings. Arjuna earrings look like tendrils of small chili plants that represent his simplicity appearance. Even though the chili is small, it feels spicy, representing Arjuna who although small and without jewelry, his charm still stands out among the other characters. Arjuna is the incarnation of Lord Indra who is the god of light so that his presence is always associated with the light that shines, so that makes it always can be marked.

\section{Face and Head Position Differences}

Arjuna's head elements in the three shadow puppets form a certain facial expression which is then seen as a pasemon (facial impression). Pasemon cannot be calculated mathematically but based on the taste of the carver, puppeteer, and audience. Pasemon is symbolic and is read according to Javanese perception.

The Pasemon embodied by Arjuna Kedhu is regu wibawa, which means it looks grand and authoritative. Arjuna Kedhu was Arjuna in his old age, although he continued to seek knowledge and practice asceticism, at that time Arjuna had gained wisdom. Arjuna wanda Kedhu is used for religious plays and is used for ruwatan (Javanese ritual).

Pasemon Kinanthi is kalem-mesem-mengkusuka (means peaceful, smiling, happy), which means Arjuna is in a calm and happy atmosphere. Arjuna Kinanthi is used when Arjuna is happy because he is in love and is attracting the attention of the opposite sex. Even though puppeteers use Arjuna Kinanthi in two different conditions, namely when he is in love and when fighting, Arjuna is not being depicted in a state of anger. This is different from Arjuna Muntap who has pasemon called sereng duka (means fierce anger), which illustrates that Arjuna is in a very angry state. Arjuna wanda Muntap's anger is caused by the Kurawa killing his favorite child fraudulently.

Differentiation between the facial elements of Arjuna Kedhu and Kinanthi is generally thin. The height of the two shadow puppets' bun has the same front, although the position of the back bun is different $3^{\circ}$, and the length of the bun as a whole only differs around $0.075 \mathrm{x}$ shorter and $0.025 \mathrm{x}$ lower (see Table 2 ). The angle of the forehead is equal to $6^{\circ}$ (see Figure 3), the angle of the eye is only $1^{\circ}$ (see Figure 4), as well as the distance between the upper corner of the eye and the brow curve is only $1^{\circ}$ (see Figure 5 ). The face areas cut off by the shoulder lines in Arjuna Kedhu and Kinanthi differ by $0.125 x$ (see Figure 7). Arjuna Kedhu and Kinanthi also wear the same sumping Parisewuli motif.

The differences that are not too big between Kedhu and Kinanthi can explain how both faces have pasemon, which is in a state of calm. The feeling of calm is different from the feelings of fierce anger displayed on Arjuna Muntap, so the shapes are very different from Arjuna wanda Kedhu. The differences and expressions raised by Arjuna Muntap triggered a polemic among observers of shadow puppet. Bambang Suwarno, an expert in shadow puppets who are academics, puppeteer, and wanda experts in a personal interview on 18 November 2018 said that some people considered Arjuna's specialty was his patience, so Arjuna Muntap who displayed anger obscured the privilege. The other party considers that if Arjuna does not feel angry after his beloved son was cheated fraudulently by the Kurawa, then that is inhumane, therefore the use of Arjuna Muntap is considered appropriate in a fierce battle.

\section{Conclusion}

Arjuna's emotions are limited because of his character as an ideal man who has high self-control. Self-control means also the control of the body, lust, and emotions so that the range of emotions that can be displayed on Arjuna's shadow puppets cannot be too wide. The shadow puppets wandas that were studied represented three emotions, namely Kedhu which represented calm and pious emotions, Kinanthi which represented calm and happy emotions, and Muntap which represented angry and aggressive emotions. Kedhu and Kinanthi do not have big differences, but Kedhu and Muntap have big differences. The big difference is mainly the shape and size of the bun, forehead, and neck position that determine the position of the head. 
The differences that emerge from these three shadow puppets can be seen as gradations of expression, with Kinanthi's position mediating between Kedhu and Muntap. The feelings of happiness and falling in love displayed by Kinanthi are not as passive as the Kedhu, but also not as aggressive as Muntap. The slight difference between Kedhu and Kinanthi shows that the expression of happiness and falling in love with Arjuna wayang kulit is not too far from the expression of piety and surrender to God as in the sign of Kedhu. On the other hand, the pious and happy expressions of Kedhu and Kinanthi are far different from feelings of anger towards Muntap. But in general the shape of Arjuna Muntap is still by the general characteristics of Arjuna, namely the position of the head decays, his body is small, and the distance between his legs is tight, even just the eye elements are slightly different from the other two wanda.

\section{References}

Anderson, B.A. (2000). Mitologi dan toleransi orang Jawa. Yogyakarta, Indonesia: Penerbit Qalam.

Ch, M. Nasruddin Anshoriy. (2008). Kearifan lingkungan dalam perspektif budaya Jawa. Jakarta, Indonesia: Yayasan Obor Indonesia.

Clark, M. (2010). Maskulinitas: Culture, gender, and politic in Indonesia. Selangor, Malaysia: Monash University Press.

DeJong, S. (1976). Salah satu sikap hidup orang Jawa. Jakarta, Indonesia: Kanisius.

Deleuze, G. (2001). Difference and repetition. London, UK: Continuum.

Fiske, J. (1990). Ethnosemiotics: Some personal and theoritical reflections. Cultural studies, 4(1), 87-98

Guritno, S. (2002). Karakter tokoh pewayangan Mahabrata seri V. Jakarta, Indonesia: Direktorat Jendral Kebudayaan.

Pozzato, M. (2017). Visual and linguistic representations of places of origin. Berlin, Germany: Springer. 